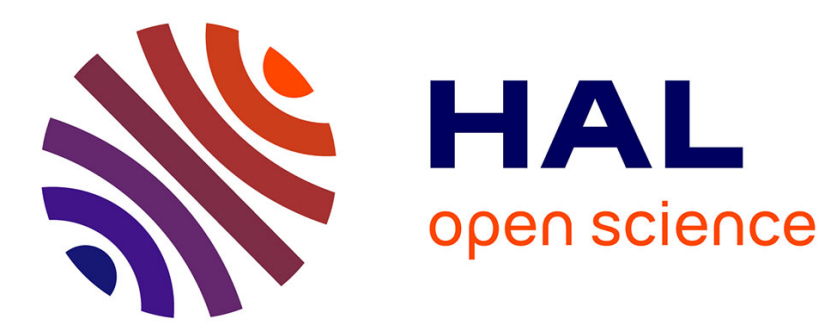

\title{
Re-thinking the conservation of carbon, water and soil: a different perspective
}

Thomas Francis Shaxson

\section{To cite this version:}

Thomas Francis Shaxson. Re-thinking the conservation of carbon, water and soil: a different perspective. Agronomy for Sustainable Development, 2006, 26 (1), pp.9-19. hal-00886258

\section{HAL Id: hal-00886258 \\ https://hal.science/hal-00886258}

Submitted on 1 Jan 2006

HAL is a multi-disciplinary open access archive for the deposit and dissemination of scientific research documents, whether they are published or not. The documents may come from teaching and research institutions in France or abroad, or from public or private research centers.
L'archive ouverte pluridisciplinaire HAL, est destinée au dépôt et à la diffusion de documents scientifiques de niveau recherche, publiés ou non, émanant des établissements d'enseignement et de recherche français ou étrangers, des laboratoires publics ou privés. 


\title{
Re-thinking the conservation of carbon, water and soil: a different perspective ${ }^{1}$
}

\author{
Thomas Francis SHAXSON* \\ Greensbridge, Winterborne Kingston, Dorset DT11 9BJ, England
}

(Accepted 21 January 2005)

\begin{abstract}
Sustaining soil productivity requires continuing actions of soil organisms on organic materials for optimizing of soil porosity and of movements of roots, water and gases in the root-zone. Soil is more quickly formed and self-renewed from the top downwards than only by slow additions from the bottom upwards. Loss of porosity diminishes soil's infiltration capacity and water-holding potential. Factors that provide insufficient organic substrates for soil organisms and that unduly accelerate oxidation of soil organic matter hinder the self-recuperation of soil and facilitate 'Stage-1' loss of carbon from within soil aggregates. They predispose the soil to lose rapidly even more carbon, in particulate form, through 'Stage-2' losses during consequent processes of runoff and erosion. Forms of land use and management are advocated that favor the functioning of soil-inhabiting organisms, including plants, such that carbon's capture in photosynthesis is increased, its usefulness in the soil as a rooting medium is prolonged, and its subsequent immobilization in the process of sequestration ameliorates the rate of increase in carbon dioxide concentration in the global atmosphere.
\end{abstract}

carbon sequestration / soil-organisms / porosity / self-recuperation / sustainability

\section{INTRODUCTION}

"After seven decades of conservation programs that have consumed millions of dollars of economic resources and vast quantities of human resources, soil erosion and subsequent degradation of water resources remain serious environmental issues within the United States.” (Napier, 2001).

The same may be said of other countries, in particular those covered by the Intertropical Convergence Zone where high temperatures and unstable masses of moist air lead to heavy storms and high intensities of erosive rainfall (Pereira, 1989). In places where farmers' capacities to manage the soil are insufficient or inappropriate for maintaining it, soil productivity is in decline, or its maintenance is increasingly costly, and the land's use less profitable. However, if even the wealthy USA, which has invested so much over so many years, has not solved this problem, then it is not surprising that other countries which adopted a similar paradigm have also not managed to prevent the degradation of their soil and water resources.

Superimposed on this broad concern is a worry, being addressed at this Colloquium, that carbon selectively removed during erosion processes may be contributing to carbon dioxide in the atmosphere and thus to global warming, adding urgency to the need to find solutions to ongoing degradation of soil and water resources. The deliberately provocative question is there- fore implied: "Is 'erosion control' (however defined) the best approach for solving these problems?"

\section{SOME ASSUMPTIONS AND THEIR CONSEQUENCES}

Many of the relevant facts about land degradation and soil erosion had been identified, and their implications assessed, by the 1940s and 50s (Bennett, 1939; Stallings, 1957). However, in many countries, governments' subsequent selective interpretations for purposes of developing policies and strategies to minimize land degradation and maintain soil productivity appear to have missed key points and misplaced important emphases.

Pronouncements about accelerated erosion's effects on soil productivity appear to have rested in part on some unquestioned but doubtful assumptions, which seem to have led also to some more or less inadequate approaches to controlling erosion. These have been typified by widespread primary reliance, in many governments' programs in past years, on physical conservation works such as terraces, bunds and silt traps. The evidence of this is plain to see on huge areas of cultivated land across many countries of the world. Such works have failed to solve the problem on their own and the problem of carbon loss

\footnotetext{
${ }^{1}$ This article has been presented at the Colloquium of Montpellier entitled "Land use, Erosion \& Carbon Sequestration" organized by the "Réseau Érosion francophone" and the Lab. MOST of IRD and CIRAD (information: Dr. Eric Roose, Eric.Roose@ird.mpl.fr).

* Corresponding author: FShaxson@aol.com
} 
through soil erosion by water was probably unnecessarily severe. The difficulty appears to arise from too narrow an emphasis on soil erosion control and too limited an application of insights from other disciplines in the development of better means for improving and sustaining the resilience and productivity of soils in the face of severely erosive climatic events.

Through much of the earlier literature and policies on soil erosion and its control, common assumptions appear to have included:

a. That productivity decline is commonly caused by soil erosion, and the relation between the two ought to be definable by knowing the quantities of soil lost: therefore measure soil loss and attempt to predict productivity changes under different scenarios.

b. That soil erosion is some sort of a force in its own right, capable of degrading land: therefore it has to be combated.

c. That runoff is the prime factor in erosion: therefore runoff must be controlled.

d. That soil productivity depends largely on its chemical constituents, and these - as well as clay and organic materials are selectively eroded: therefore fertilizers must be added to counterbalance such losses in order to maintain/raise yields. (Bridges et al., 2001; Doolette and Magrath, 1990).

This line of thinking became to an extent hallowed over time not only by respect for those who first paid serious attention to trying to solve the problems of land degradation on a large scale, but also by repetition of only selected aspects of what these pioneers had propounded. The approach, as applied in practice, has led to much dedicated research and many kilograms of reports; but it has also tended to 'tramline' thinking and action towards ever-more detailed investigation of the same parameters, and the application of more refined forms of the same erosion-control technologies. It has not fostered much lateral thinking about the subject as a whole.

So, the common response has been to 'fight erosion' with 'erosion control', which has often translated, primarily through government policies, programs and projects, into the construction of physical works to control and divert runoff and contain the soil it carries. For many, 'soil conservation' and 'erosion control' appeared almost synonymous. Even with financial inducements, farmers have not responded to this approach very enthusiastically, and these approaches have not often been widely adopted on the one hand nor, on the other, is there much evidence that these physical works, on their own, have improved the quality of the soil (even though they may have slowed the rate of gross soil loss). The justifications for recommending such an approach are further diminished by the difficulty that quantitative erosion-productivity relationships for most soils are not known (Eswaran et al., 2001; Sonneveld, 2002), although such information for a number of soils in tropical and subtropical regions has been clarified in recent years. (Stocking et al., 2002; Stocking and Tengberg, 1999; Tengberg and Stocking, 2001).

A result has been that many conservation enthusiasts tended in the past to assume they were correct in their analyses of land degradation and that farmers were resistant in not sharing the faith or favoring the recommendations made. The only way to improve this unsatisfactory situation appeared to be for governments to pressure farmers more strongly, and/or reward them more generously, until they readily complied. However, the reason for non-adoption by farmers is more likely to have lain in the frustration they felt at not being able to get advice that is relevant to their problem of falling productivity: this implies a need for advice that can be seen to be effective and that is both feasible and of net benefit - or at least of no net disadvantage - to their farming enterprises.

The danger has been that, without adequate proof that such an approach can solve problems, governments might become disillusioned and reduce support for seemingly unproductive investments in 'SWC' (soil and water conservation), as occurred in, for example, the case of Lesotho in 1990 where continuing support for an aid program for soil conservation was withdrawn (author's experience).

While there has been developing a growing awareness, over the last three decades in particular (Hudson, 1981), of a wider range of ways of addressing the problem, it has still been necessary to point out recently that 'there is a need to re-think what we are doing, rather than re-fashioning dated concepts' (Hannam, 2001).

This paper contributes to this necessary re-thinking.

\section{VIEWS FROM A DIFFERENT VANTAGE-POINT}

\subsection{Some anomalous results}

There exists a small number of 'inconvenient' results of erosion's effects on productivity that open a mental door to another perception. Some researchers have recorded certain instances, in research plots and in farmers' fields, where yields have risen rather than fallen after significant erosion has occurred (e.g. in Malaysia (Morgan, 1995), Papua/New Guinea [Kerr, pers. comm.] and Australia [Sanders, pers. comm.]. An example of such a condition of the soil is illustrated, for example, in Lesotho (Shaxson and Barber, 2003). Though the number of such recorded instances is very small it would be unwise to discard such apparently anomalous observations as mistakes or as special 'exceptions which prove the rule' because, in fact, they are important pointers to an unacknowledged but significant reality.

These odd observations indicate that the condition of a previously subsurface layer was better for rooting than that of the former surface layer; it was exposed at the surface (before the next season's crop was sown) when the topmost layer had been stripped off through erosion (Shaxson, 1997). This is in direct contrast with the more-common situation, where the subsurface layer that has been newly exposed by erosion is poorer for root growth than that which formerly covered it.

\subsection{Different considerations}

Reassessment of some already known facts allows some alternative interpretations of the assumptions a, b, c and d noted above:

a. Difference between yields before and after soil erosion is more clearly related to differences between in-situ characteristics of the soil as a rooting environment before and after erosion than to the quantity of soil removed (Shaxson and Barber, 2003). The quantity and chemical quality of eroded soil provides an inadequate explanation of soil-productivity decline. 
Three-dimensional pore spaces and interlinkages of soil particles, organic matter and soil micro-organisms are important for good root-growth and function in the surface layers of soil, as also at subsurface levels (FAO, 2001; Wild, 1988). While this is acknowledged in the recent study of erosion:productivity relations (Stocking and Tengberg, 1999) their damage and loss is more attributed to the erosion process itself, rather than damage to them being perceived as a precondition for accelerated erosion and runoff.

A more effective strategy to maintain soil productivity should therefore emphasize protecting the soil surface and favoring the improvement of the complex integrity of the soil which remains in place into a good condition for the growth and functioning of roots. In this instance, this is a matter of changed emphasis rather than changed approach: emphasize the accelerated protection and improvement of what remains in situ (positive view) more than regret that which has been lost (negative view).

b. Undue erosion is a foreseeable ecological consequence of changes (often management-induced) in relations between the components of the natural environment both above- and belowground - geology, topography, vegetation, hydrology, soil, fauna and flora - all under the influence of climate, gravity and the effects of people's actions.

From soil not adequately protected from erosive raindrop impact the active movement of eroded soil during a rainstorm is a visible manifestation that this adjustment is happening. It may be occurring as a result of a detrimental change in the condition of the surface soil, resulting in the ecosystem at that place changing from one level of meta-stable equilibrium to another, often (but not necessarily always) of lower productivity (Downes, 1982).

If this is true, then soil erosion itself is not the first cause of destabilization and soil loss. The predisposing cause is a disturbance to the balance among environmental factors, which is often provoked by people's damage to the soil's cover and its three-dimensional architecture through inappropriate management.

c. Runoff control measures offer barriers/diversions in the lateral dimension, after water has begun to flow down-slope. They have no effect on the prior impact of erosive raindrops falling in the vertical dimension, which cause splashing of soil particles, hammering of the surface, and its interstitial sealing by filtered-out fine particles, with loss of infiltration capacity through the first few millimeters of the soil surface and rapid saturation, thereby provoking runoff at the air/soil interface. If the porous condition of the surface can be maintained and improved by the interpolation of a permeable organic cover between rain and the soil surface, infiltration rates can remain surprisingly high, with little or no partition of the rainfall into runoff.

In this context physical cross-slope works against runoff are 'blunt instruments' for keeping the root-zone intact and in place, and not very effective substitutes for (though useful complements to) adequate amounts of cover, and good water-stability of the soil aggregates, against damaging effects of rainfall. d. Soil productivity, as expressed through plant growth, inheres in the dynamic interactions between its physical $x$ chemical $\times$ biological $\times$ hydric constituents that define the soil as a rooting environment, and not merely in a reservoir of useful chemicals (Squire, 1990; Wild, 1988). Both plant roots and soil moisture need to be explicitly identified as constituents, otherwise they tend to get overlooked when hidden within the 'biological' and 'physical' segments.

Soil moisture at plant-available water potentials is a key control of soil productivity. The effect of its inadequacy on plant growth functions is almost immediate - within hours or days rather than weeks - not only after the transpiration rate is diminished by slowed water transfer from soil to roots, but also as stressed plants are revived when rainwater re-enters the desiccated root-zone.

A range of pore sizes enables water to be held in the soil at a range of water potentials (in $\mathrm{kPa}$ ) between Field Capacity and Wilting Point which is available to the transpiration stream of plants under the influence of evaporative demand (Allan and Greenwood, 1999). Pores which are large enough to allow free drainage to below the root-zone allow excess rainwater to pass downwards towards the groundwater.

Components of any soil productivity-enhancing strategy should therefore include (a) whatever is necessary to ensure that rainwater can enter the soil without avoidable hindrance, (b) that the soil is maintained in an appropriately porous physical condition to retain high proportions, or all, of its soil moisture at low tensions, so that plants can retrieve it readily, and (c) that unproductive water loss by direct evaporation from the soil surface is minimized.

\subsection{Soil porosity and biological activity}

Soil porosity based on water-stable aggregates is of primary importance in the joint consideration of both soil productivity and soil erosion, because it moderates the movement of water, gases and roots within the soil.

In undisturbed conditions, both the physical processes of wetting, drying and weathering, and - under favorable conditions such as in the forest floor, prairie grasslands, well-managed pastures, and other managed situations rich in organic materials - the effects of biological activity contribute significantly to the build-up and maintenance of soil porosity. This is a consequence of (a) the activities of micro-organisms such as bacteria and fungi in transforming organic materials into humic gums, which cause soil particles to clump together into irregularly-shaped aggregates, within and between which are the voids which form useful soil pores; (b) the expansion and subsequent decay of roots which leave tubes of various diameters in which organic materials have been disintegrated and transformed, and (c) burrowing activities of mesofauna such as termites, worms, and other soil-inhabiting fauna. Water acceptance is very high, a situation less often found under conventional tillage systems than under residue-based no-till systems.

The literature abounds in references to soil organic matter, but the same seldom refer to the parallel necessity for the presence of active soil organisms which can effect its transformations. If the soil is inimical to their activity - too low in organic matter, too hot, too dry, too acid, etc. - soil-benefitting transformations do not take place. In the author's experience in Lesotho, for instance, maize-stalks and leaves that had been ploughed-under three years previously re-appeared unaltered 
(and thus of no benefit to soil structure) when the field was again ploughed because there was no biological activity in the soil.

The combination of sufficient organisms, organic materials, water and nutrients in soil provides for the continuing resurgence of biological activity from year to year. Maintaining a good soil architecture - a soil with the pore spaces and structural stability that is most conducive to biological productivity depends on (a) not losing it in the first place, and (b) if it has become damaged, its rapid recuperation. This latter can only be achieved by the microbially-induced transformations of organic matter to form the aggregates that both contain and bound the spaces in the soil, where life goes on, where waters and air move. On the one hand, there must be self-perpetuating populations of living organisms to effect such transformations, and on the other, there must be permanent or recurrent supplies of organic materials as a sufficient substrate for their activities. These may be variously provided by roots themselves, by the retention of residues from previous crops, and by transportingin of organic materials from elsewhere as raw or composted additions.

In the majority of agricultural situations (in cropland, pasture, forest land and rangeland), the key factors for avoiding (rather than controlling) runoff and erosion are surface cover and soil porosity. Both depend on living organisms, plants and other soil inhabitants, and their proper husbandry, which thus contributes to extending the useful life of carbon in complexes within the ecosystem and to preventing its premature return back to the atmosphere.

\subsection{Tillage and the loss of soil pores}

Ploughs and discs, and even hand hoes (Shaxson, 1999), through their capacity to shatter aggregates, excessively aerate the soil, leading to high rates of organic-matter oxidation, which can cause severe subsurface compaction.

Tillage provokes not only gross physical alteration to soil architecture but also results in accelerated oxidation of dead organic matter by soil organisms, with the untimely release of respired carbon dioxide back to the atmosphere (Mrabet et al., 2001a; Reicosky, 2001; Stewart, pers. comm.).

Exposure of unprotected soil to direct solar radiation also results in breakdown of the complex organic materials which give coherence and stability to soil aggregates, resulting in the collapse of soil architecture, loss of pore spaces and densification of the soil.

This tillage-induced oxidation can quickly negate the carbonaccumulating effects of photosynthesis, thereby short-circuiting and hindering the possibility of any subsequent processes of carbon sequestration by more profound immobilization.

Repeated oxidation induced by tillage has often also resulted in net depletion of earlier-accumulated soil organic matter (as in chernozems in C. Asia, and other 'over-worked' soils across the world). The process occurs more rapidly in warmer climatic zones of the world.

In different situations some or all the carbon fixed by plants may therefore not persist beyond the first year in the soil - next year's tillage can result in loss of some/most/all the carbon fixed by photosynthesis in the previous year. The benefits of rotational cover-crops and/or rotational pastures in improving soil conditions can be more or less completely undone again by any tillage which subsequently actively incorporates them back into the soil (Hudson, 1981).

Loss of pore spaces from the soil, whether due to compaction, collapse, pulverization, oxidation of organic matter, or interstitial sealing, represents loss of useful voids in the soil matrix, hindering or even preventing exploration by root-hairs and root-tips, expansion of maturing roots, movements of water and gases and, from the moist boundaries of these spaces, the absorption of nutrients (McGarry, 2002).

These spaces are comparable with rooms in a building: all the important activities take place within the voids, not within the structural materials themselves. Their loss is comparable to the effects of demolishing a building: the mass of the rubble, glass, steel beams and other construction materials is the same, but the value of those materials has vanished because the useful spaces of the architecture have disappeared. Loss of pore spaces in the soil diminishes the value of the physical component of productivity.

This damage to soil architecture, at the surface and below, results in quicker saturation of affected soil horizons and an increased likelihood of early onset of runoff.

The improvement of soil by getting organic matter back into the profile is best achieved by soil-inhabiting organisms. Their energy comes free of charge and their actions tend, directly or indirectly, to improve the porosity of the soil. Heavy farm equipment's physical effects cannot emulate, nor even simulate, organisms' biological effects on improving soil condition.

\subsection{Towards sustainability - prolonging the usefulness of resources}

Throughout the history of agriculture, soil conditions have been modified by people's activities, and native vegetation widely substituted by other plants capable of producing higher yields and/or different plant products of greater use to people. Ideally, the substituted systems of use and management should be at least as stable and biologically sustainable in the face of the range of anticipated recurrent weather conditions as the native ecosystems they have supplanted.

The GAMMA Project of the universities in Montreal defined 'conservation' as 'prolonging the usefulness of resources' (Downes, 1978). In the context of this paper, resources of carbon, water and of life itself (expressed in the forms of e.g. soil-inhabiting plants and organisms) can properly be included in the development of this capacity.

Schrödinger indicated that, "metaphorically, the most amazing property and capacity of life is its ability to move upstream against the flow of time" (Lovelock, 1988) with the capacity to assemble complex energy-rich materials against the otherwise opposite entropic tendency of breakdown to simpler units, which is accompanied by dissipation of energy as time progresses. This capacity of life provides a common thread which interconnects both concepts and dynamic aspects of 'ecosystems', 'soil health', 'resilience' (of both soils and plants), 'sequestration and combination of carbon', 'self-recuperation capacity' (of ecosystems and their living components), and 'sustainability'. 
Improvement of the soil as a rooting environment leads to more carbon capture by plants, increasing the cycle of mutual benefit. It also favors retention of this carbon within the soil, and further prolongs its usefulness by increasing the net amounts which are subsequently sequestered in relatively immobile forms. The concomitant sustaining of soil quality and of water-holding and water-transmitting capacities can greatly diminish the volumes of surface flow of excess water, and hence most or all losses of organic-matter particulate fragments in erosional runoff.

Better management of landscapes therefore contributes significantly not only to increased stability and productivity (of water and of plants) in agricultural and other ecosystems (Haigh and Gentcheva-Kostadinova, 2002; Shaxson and Douglas, 2004) but also, and simultaneously, to lessening the quantities and detrimental effects of carbon dioxide gas in the global atmosphere.

Managing an organically-rich agriculture ensures the regular addition of organic materials to the soil surface by crop residues and cover-crops, manures, etc. These protect the soil surface, provide food for the soil organisms and raw materials for transformation by them, and keep humic materials already within the soil in conditions that are shielded from ultra-violet solar radiation, which is capable of breaking chemical bonds in organic molecules.

Results from unirrigated residue-based no-till (NT) systems for a range of crops in Brazil (Landers, 1998), from mulching experiments in many situations (e.g. on young tea in Malawi (Tea Research Stations, 1963) and from NT wheat in central Italy (Pisante, pers. comm.) and Morocco (Mrabet, 2002) in areas of annual rainfalls ranging from about 2000-300 mm) show that improved surface-cover conditions - by diminishing direct insolation of the soil surface - prolong the usefulness of both rainwater and carbon in the soil. This enabled longer duration of early growth of young plants of tea (a perennial crop), and of duration of grain-filling of durum wheat (an annual crop), by delaying the onset of growth-inhibiting moisture stress when rainless conditions set in during and at the end of a rainy season (Shaxson and Douglas, 2004).

To obtain the full carbon-capturing effects of 'no-till' agricultural systems, it is essential, as a first task, to bring the soil to good condition for water acceptance (possibly involving subsoiling, etc., to break any earlier induced compacted layers at or below the surface). Then the retention of crop residues in the field becomes the means of ensuring net additions of organic matter, which are gradually and progressively incorporated by the soil biota into the soil matrix of the root zone and below. Such systems have the characteristics of (a) continually adding to the soil surface the raw materials for biological transformation into soil organic matter and (b) reducing rates of oxidation of the same organic matter by precluding unnecessary mechanical disturbance of the soil and thereby avoiding its excess oxygenation.

These aspects of the continuity of biological activity and of self-recuperation over time are fundamental to the sustainability of chosen land uses. These results were formerly achieved by 'resting' the soil (allowing/enabling biological self-recuperation of the soil) between phases of intense production. In traditional tropical agricultural systems, 'bush fallow' periods of maybe as long as 50 years were used in long rotational cycles with crops and pastures (Wrigley, 1961; Critchley et al., 1992).

Given today's increasing pressures of population, many small-holders' declining farm size and persistent poverty, a major challenge is to achieve the same degree of sustainability by simulating fallows' restorative effects very much more quickly. Even in rotational cropping systems which involve tillage, three options (preferably used together, for synergy) can be outlined:

* Increase the soil's biological capability for recuperation assist more organic activity.

* Reduce the time during which the soil suffers damage rotate crops at shorter rather than longer intervals (Hudson, 1981).

* During the period of suffering damage, reduce the severity of its impact: use equipment, pasture-management, etc., which is least damaging to soil in optimum root-favorable condition, in preference to practices capable of causing adverse mechanical disturbance (Shaxson, 1993).

\subsection{Soil as a renewable and self-renewing resource}

Many consider soil to be, in practical terms, a non-renewable resource (e.g. Critchley et al., 1992). This perception relates to the slowness with which a soil's deep parent materials are weathered into root-usable materials. However, in situations where organic matter and organisms accumulate on and within the upper horizons of the soil, the rooting-zone is enriched and increased. (Shaxson, 1981). Further, it is possible that organic acids moving down from the surface may raise the rate of 'weathering' of mineral particles and so liberate nutrient ions within the root-zone.

Soil can thus be said to be formed top-down as a recurrent process, almost independent of deep weathering (Wild, 1988); (Fig. 1).

Based on this understanding, soil restoration and development can be actively implemented in agricultural systems, more rapidly than with unimproved fallow periods, by using residue-based zero-tillage systems, as in Brazil (Derpsch, 2001; Landers, 2001). By the same token, former thinning of soil depth by erosion may also be reversed by improved forms of soil management that encourage the accumulation of organic matter in the soil surface layer. In different farming situations in a number of countries in the tropics and subtropics this is dramatically achieved also with the occasional/rotational use of e.g. Mucuna spp. as a dense clambering smother-crop across the field surface (Shaxson, 1999; Stocking, 2003). This provides excellent control of weeds, thick and complete cover of the soil, and large quantities of nitrogen-rich biomass whose fallen leaves produce excellent litter beneath, as a food source for the soil biota, leading to increase in the soil's content of organic matter. In other situations, various legumes such as Tephrosia vogelii and Vetches (Vicia spp.) are used to achieve similar improvements in soil quality. (Shaxson and Barber, 2003). This accumulation of carbon, with associated improvements in the physical and chemical qualities of a soil, is generally accompanied by a rising potential for increased productivity. 


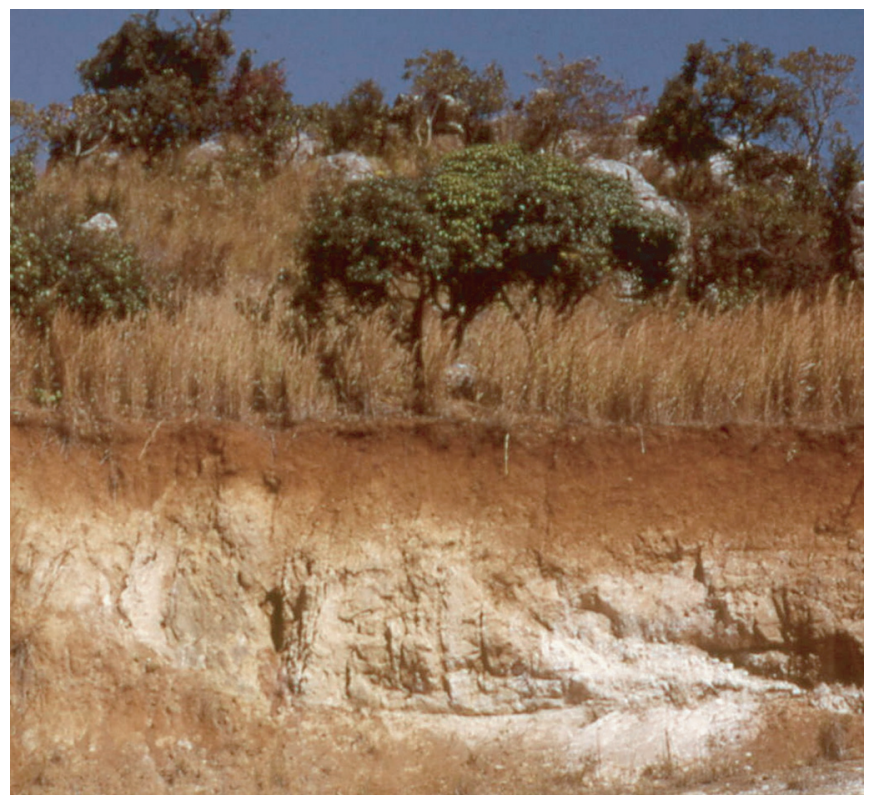

Figure 1. Progressive top-down formation of the rooting environment through plants and other soil-inhabiting organisms contributing and transforming organic matter, combining with the effects of chemical weathering in the development of a soil. Kasupe, Malawi. (T.F. Shaxson).

\subsection{A biological definition of soil}

Many scientists include soil biology as a defining characteristic of a soil. A weathered layer that has no soil is called regolith, or sediment if it has been transported across the environment. A true soil is a biologically constructed zone at the interface between rock and atmosphere. It is reasonable, therefore, to argue that soil should be valued more for the dynamics and diversity of its living components, which benefit plant production, than only for non-living pedological characteristics such as its arrangement of horizons, range of mineral-particle sizes, and/or parent materials.

Arguably, society might may take better care of soil if it were considered less as an inorganic physical unit of mineral particles, air, water and nutrient ions that happens to contain life, but more descriptively as a living system, a complex and dynamic subsurface ecosystem of diverse living organisms (including plant roots), non-living organic matter, and biologically-transformed organic/humic products, which inhabits, modifies and interpenetrates an inorganic mix of mineral particles, air, water and nutrient ions, and which changes dynamically over the fourth dimension of time.

\section{LAND HUSBANDRY INFLUENCES}

\subsection{Effects of good land husbandry}

Principles of good land husbandry (Shaxson, 1993; Downes et al., 1997) are shown in Table Ia, b. In the field they are well illustrated by an increasingly large number of Brazilian farmers, for instance, who have developed integrated residue-based farming systems with minimal soil disturbance whose total area has grown from around 1000 to more than 14 million ha in 30 years (Pieri et al., 2002). These systems specifically pay attention to improving the protection and sustainability of soil productivity (Fig. 2). They combine commercial crops, legumes and cover-crops with no-tillage and direct drilling in rotational systems of farming. The principles of soil protection and improvement may be extended to managed pasture-based systems also. Benefits include, among others: greater yields and their stability in the face of unpredictable vagaries of weather/ rainfall; improved conditions of soil architecture accompanied by greater water-holding capacity; lowered costs of production; release of space and time for diversification of crops and of people's activities; much-reduced soil erosion and surface runoff; more reliable and increased stream flow; reduced floods and related infrastructure damage, and reduced costs of maintenance of rural roads and of water treatment for urban consumption (Landers, 1998, 2001; Mrabet et al., 2001b).

Increased attention to prolonging the usefulness of carbon (in organisms and organic matter) on and in the soil is being shown, by e.g. the Brazilian experiences with residue-based NT systems, also to have positive hydrological effects - via benefits for soil porosity as well as for water storage, not only as soil moisture but also groundwater. The results are (a) to diminish the duration of, and damage to plant production by, infrequent but significant periods of drought, and (b) to make streamflow more regular and prolonged, whose corollary is to lessen the frequency, duration and severity of floods, following uncommon amounts of rainfall (Landers, 1998).

Conventional soil bulk-density measurements alone may not adequately explain observed positive improvements in water function because soils under residue-based NT systems are also penetrated by scattered but significantly large diameter wormholes and root tubes which may not be adequately sampled.

\subsection{Effects of poor land husbandry}

By contrast, poorly managed systems - which by overgrazing, fire or excessive tillage, for example, allow or encourage breakdown of the complex compounds of carbon ('Stage-1 carbon-loss') in porous soil aggregates - thus pre-dispose the land to lose yet more carbon, as particles of litter and other organic remains, in subsequent processes of erosion and runoff ('Stage2 carbon-loss').

Concentrating attention only on the Stage- 2 carbon-loss (as in 'erosion-control' work) fails to take sufficient account of the effects of the preceding Stage-1 loss of carbon from the ecosystem. This sidelines the very serious and far-reaching consequences of poor land husbandry, which include the increasing exposure of the soil surface, decline in soil-structural stability, diminution of soil porosity, lowering of productivity, and consequent increases in occurrence and severity of runoff, erosion, and water stress in plants (Fig. 3).

\subsection{The need for better land husbandry}

All farmers who depend on the land try to look after it ('husband' it) in one way or another - some better, some worse. Land degradation and loss of productivity (of both plants and of water) is a usual and widespread result of poor land husbandry. Writings about land husbandry in English (e.g. Shaxson et al., 
Table I.

(a)

Better Land Husbandry - Altering Some Technical Perceptions

\section{NEWER VIEW}

1. Chief causes for concern are (a) decline of land's in situ productive potentials, and (b) insufficiency of soil moisture.

2. Improving and managing soil to ensure optimum rainwater absorption and retention will have more sure and widespread effects on plant production than only constructing physical cross-slope works to catch or direct runoff water and soil already on the move.

3. Accelerated runoff and erosion are foreseeable ecological processes, and consequences of other aspects of land degradation.

4. Post-erosion yields at any site after erosion are closely related to the quality of soil which still remains in situ.

5. Rainfall's erosivity can be minimized by breaking the force of large raindrops by ensuring some form of cover over the soil surface.

6. Soil's erodibility is increased or diminished over time by effects of management of the soil.

7. More intensive use of land at a particular site - such that it (a) improves soil architectural conditions by favoring soil-organic transformations and minimizing tillage-damage, and (b) increases density, duration and frequency of cover over the soil - can improve rather than diminish conservation-effectiveness of the particular use.

8. Increased production of plant parts - with improvements in soil architectural conditions, and in the amounts of cover over the soil is an effective way of achieving conservation of water and soil as a consequence of better husbandry within the farm production system.

9. Because the land system is dynamic, maintaining its capacity to continue producing what we want requires its active and conservation-effective management over time, at the same time as any re-allocations of land uses and imposition of any necessary physical works.

10. Solving problems of low productivity and of erosion and runoff requires an inter-disciplinary approach to match the inter-relatedness of the problems' causes. etc.
OLDER VIEW

1a. The primary cause for concern was with quantities lost of soil particles and water.

2a. It was commonly assumed that cross-slope physical conservation works would result in significant increases in yield, by holding back soil, water and nutrients in narrow bands across the slope.

3a. Accelerated runoff and erosion were visualized as primary active causes of land degradation.

4a. It was generally assumed that decline in yields post-erosion could be related closely to quantities of water, soil particles and plant nutrients lost in the erosion process.

5a. Erosivity of rainfall was usually implicitly assumed to be an unalterable feature of each rain event.

6a. Erodibility of a soil series was assumed to be an inherent characteristic of that series.

7a. If at a particular site the land use was 'too intensive' for the Land-Use Capability classification of that site, it was recommended to reduce the landuse intensity until it matched that permitted for that Class.

8a. It was usually insisted that soil conservation be done/implemented before yields could rise.

9a. It was implied that land would be least subject to erosion when its uses are allocated across the land in accordance with maps of 'Land-Use Capability Classification', and treated with types and layouts of physical and biological conservation measures.

10a. It was assumed that soil conservation required a mono-disciplinary specialist approach, independent of other specializations, and needing separate institutional arrangements.

etc.
1989; Chinene et al., 1996) are paralleled by those in French (Roose, 1996). Improvements in land husbandry are necessary to move from the 'poor' condition (still all too common) to the 'good' condition, and then to sustain it. It should aim to assist the plants and other organisms of the chosen agro-ecosystem to optimize between themselves the dynamic relations between the physical $\times$ biological $\times$ hydric $\times$ chemical components of the soil's productivity, aided by farmers' decisions and actions.

\section{CONCLUSION}

The points discussed above appear to accord more closely with agro-ecological realities in the field than do some of those provided by the earlier common paradigm which had been widely accepted for so long. There are, therefore, a number of implications which should alter the balance of emphases in research, training and advisory work, as well as in the policy framework within which they would more effectively foster better land husbandry, leading to biologically-sustainable land uses.

\subsection{Implications for research}

Through reading potentially relevant technical literature and reinterpreting the basic research data which is reported there (as well as re-examining one's own understanding of field experiences), it may be found that much of the detail needed to fill in 
Table I.

(b)

Better land husbandry - altering some socio-economic perceptions.

\section{NEWER VIEW}

11. Farm families have their own observations and perceptions about land degradation, and other views of the reality than those of non-farm agriculturists/specialists: they should be allowed to judge what is best in their situation.

12. The rural community, and the development of its abilities to manage its own environment, is the most appropriate focus of development assistance.

13. Resource-poor small farmers have considerable knowledge about their environments, and make rational decisions about allocation of their resources within the 'envelopes' of constraints within which they make those decisions; the challenge is to lessen constraints and improve the shape of the 'envelope'.

14. Rural families ultimately decide what will be done on the land, and whether it would be in their interests to change according to recommendations; resource-poor small farmers are more vitally concerned than any outsider to maintain their lands' productivity in both the short and long term.

15. To get conservation-effective agriculture improved, it is important to start from where people are now, assist them to do better what they are already trying to do, and remove constraints that inhibit their doing better.

16. A community, and the land it occupies and uses, is the optimum focus for village planning, and for integrating inputs of various 'disciplines'.

17. 'Participation' signifies technical advisers participating with farm families in helping people to identify and rank their most important problems, to decide what do about them, to implement decided actions, and to monitor the outcomes.

18. Advisory workers should be promoters of dialogue and of twoway information transfer, catalysts of interactions, and facilitators of interchange and of farmers' well-informed actions.

19. Until they have proved themselves to the satisfaction of individual farmers, technical advisers have very low credibility at the outset of their interactions with farm families.

etc.

\section{OLDER VIEW}

11a. Specialists' perceptions of the land degradation problems and solutions were presumed to be the correct ones: outsiders should judge what is best.

12a. Land conservation, production and economic efficiency have usually been proposed as the primary foci for development assistance.

13a. It was implicitly, or even explicitly, assumed that small resource-poor farmers are by nature conservative, irrational and ignorant of good land use; the task was to change farmers' rationality.

14a. Governments assumed that they decide what would be done on the land, as they assumed they had a greater long-term concern to maintain productivity and halt land degradation than do small farmers with (supposedly) short-term time-horizons.

15a. Adoption of recommended changes and innovations were promoted as being essential for getting agriculture moving.

16a. The topographic catchment/watershed, with the people it contains, was stated to be the logically optimum unit for planning, and for demonstrating the effects of technical recommendations.

17a. 'Participation' was commonly taken to mean 'the people participating in implementing plans', devised by outsiders, which are considered good for them.

18a. Extension workers were trained as demonstrators and one-way transmitters of information to farm families, in a process of 'transfer of technology'.

19a. Technical advisers armed with scientific knowledge assumed themselves to be $100 \%$ credible from the outset.

etc.

(Downes et al., 1997). the picture of sustainable organically-rich agriculture, as sketched above, already exists.

However, additional experimentation may be needed to disentangle the real effects of improved soil-moisture conditions in the three dimensions of space and the fourth dimension of time from those of erosion control itself, with respect to their comparative effects on plant growth. There are indications that some of the plant-growth benefits attributed to 'erosion control' are in fact attributable to benefits of additional soil moisture due to the measures used, such as cross-slope trash lines, 'fanya juu' terraces, and conservation banks, where runoff has accumu- lated locally along upslope sides of the banks, and thus had more time to soak in than where runoff had been diverted along a cross-slope shallow gradient (Hudson, 1992; Hellin and Haigh, 2002; Shaxson, 1999).

Research is needed to determine, in specific situations of cropland, pasture, rangeland and forest land, what proportion of declining production of biomass (at a constant, not rising, input cost) is due to (a) insufficiency of plant nutrients (as commonly supposed) and/or to (b) root impedance and soil-moisture deficiency following loss of soil porosity by whatever cause. 


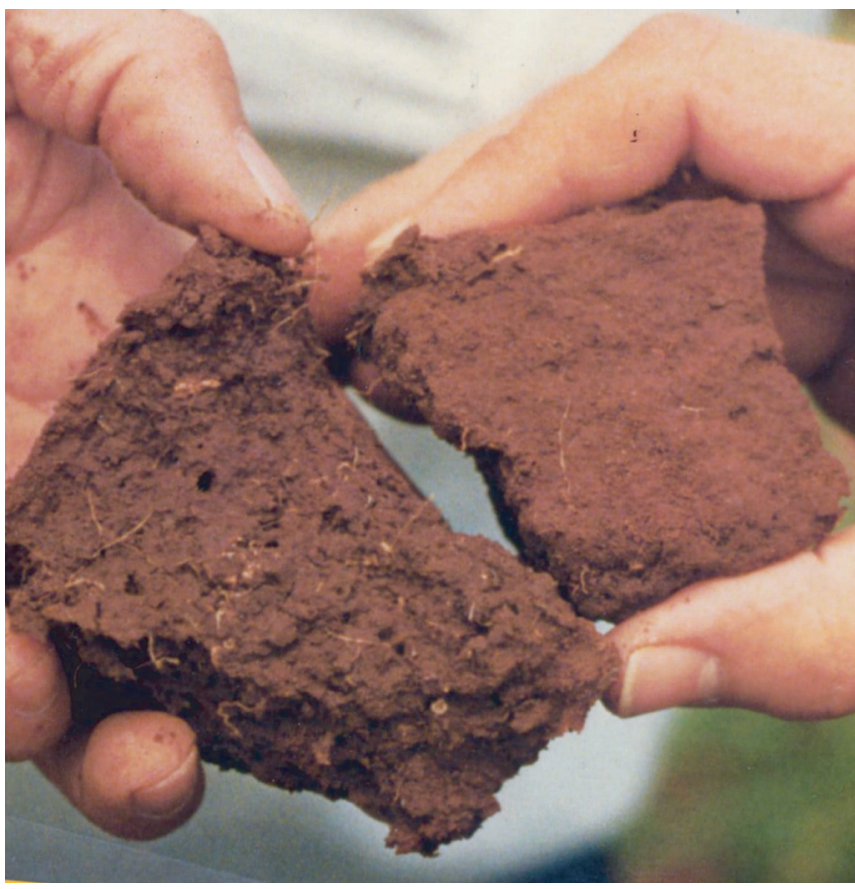

Figure 2. From this farmer's own comparative field trial, the clod of soil on the right represents the farm's soil conditions after many years of conventional tillage with disc equipment and removal of crop residues. After less than five years of no tillage plus directdrilling through the retained crop residues, the clod on the left shows the major improvements in organic-matter content and in soil porosity that have been achieved as a result. Ponta Grossa, Brazil. (T.F. Shaxson).

The contention that the difference between soil conditions before and after erosion provide a better explanation for yield difference than the quantity of soil eroded needs investigation, with a view to resolving the uncertainty about the 'grey box' of the soil loss/yield loss relationship (Stocking and Tengberg, 1999; Stocking et al., 2002).

In view of the great need to extend plant growth into rainless periods and dry seasons, emphasis in plant-breeding may be directed to selection for root systems better capable of exploring soils for stored moisture that can freely enter the transpiration stream.

\subsection{Implications for training and advisory work}

While the difficulties of implementing such an approach and strategy may be considerable in various socio-cultural and agro-climatic situations, notably in small-farmer and subhumid and dryland areas, the ecological principles remain valid in all situations. The challenge is to assist farmers to devise appropriate means of putting them into harmonious practice - using the resources of rainwater, soil, organisms, organic materials, and the energy available to themselves as farmers - to their better advantage and in ways that are simultaneously productive, sustainable and conservation-effective.

This implies the need for training advisory staff in the principles and practice of better land husbandry, in both its agroecological and socio-economic aspects, building on, expanding

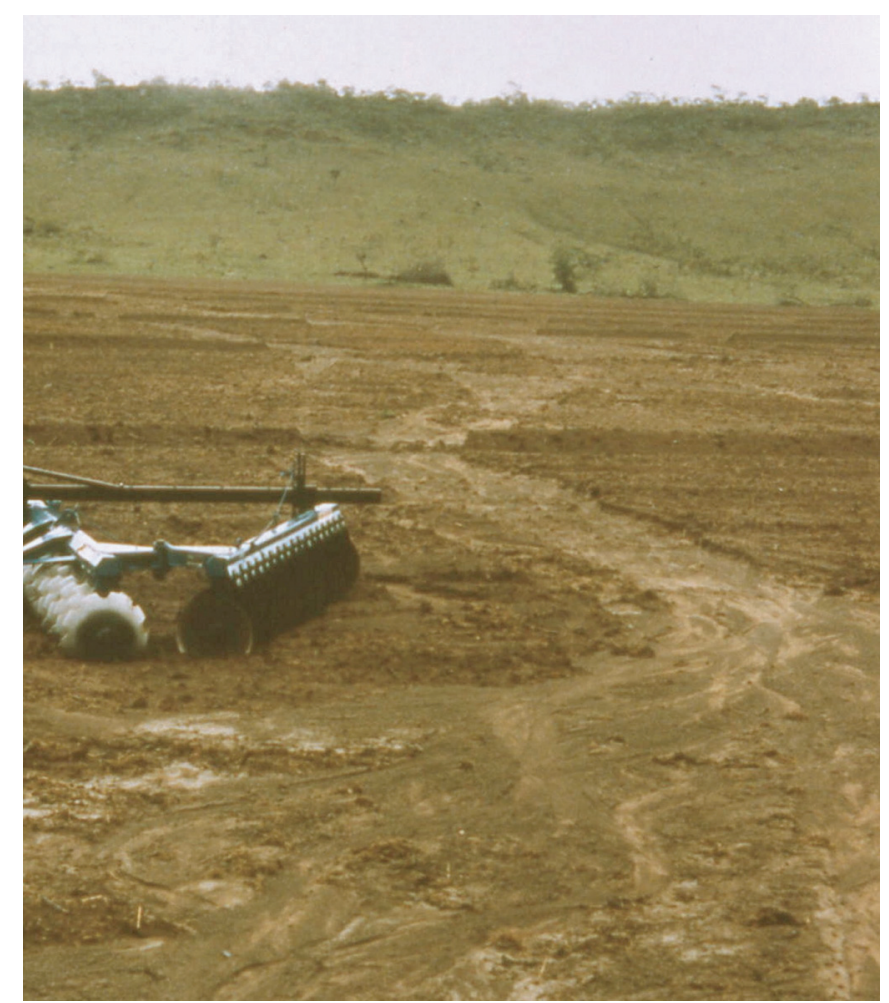

Figure 3. Stage-2 carbon loss has occurred due to erosion, following Stage-1 carbon loss via oxidation of organic matter and associated degradation of soil architecture, compounded by compaction due to conventional disk-tillage, over only a few years. São João de Aliança, Brazil. (A.W. Bell).

and, where necessary, remoulding knowledge they already have so as better to fit those realities. It is important to appreciate and show the two-way linkages between components on the micro-scale (root hairs, soil pores, bacteria, ecosystems, etc.) and those on the macro-scale (weather, landscape, landuse systems, institutions, etc.). A key need in such training is to match the ecology of agro-environmental situations being considered with the ecology of disciplines that teaching staff need to deploy for their training activities.

Moving to organically-rich systems of agriculture with much-improved soil-water relations greatly reduces the hazard of soil erosion in a given place, because the soil is better protected against raindrop damage and is more porous and absorptive. Therefore the technical 'erosion-hazard' class of a particular land unit - commonly assigned VIII-I from 'least safe' to 'most safe' (Shaxson et al., 1977) can be up-graded (e.g. from hazard-class IV to III, etc.), indicating greater flexibility of safe use and a wider range of suitable land-use types which could safely be allocated. By this means the 'marginality' of lands which are increasingly being brought under tillage by small resource-poor farmers can be modified by improving their organic quality and reducing their hazards of being eroded out of production. This would help to resolve the dilemmas encountered when attempting to classify land as 'non-arable' which is already covered with people already making arable use of it, as is often the case on steeplands in the tropical regions. (Shaxson, 1999). 


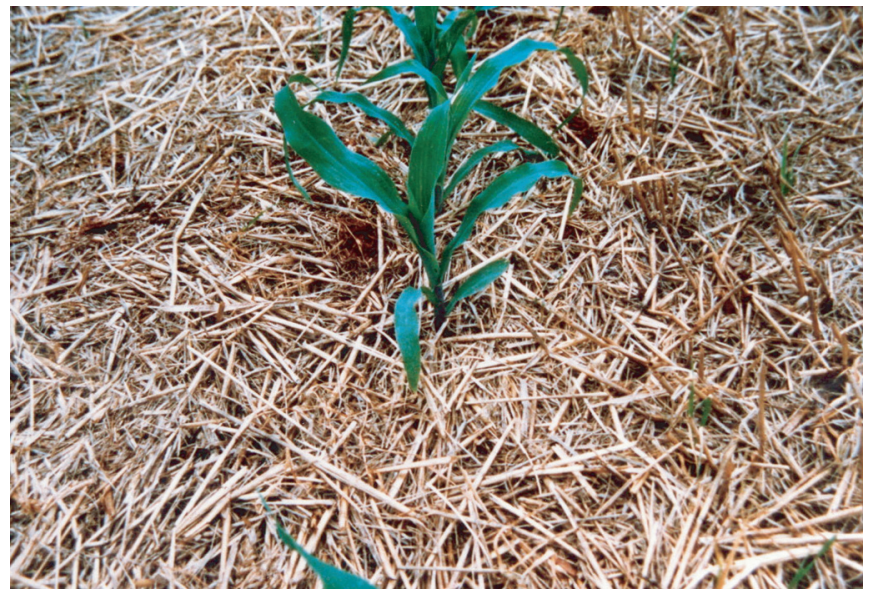

Figure 4. Residues from the previous crop provide multiple benefits for soil as the rooting environment: (a) cover which protects it against high-energy raindrop impact, high temperatures and ultraviolet solar radiation; (b) organic substrate for feeding soilinhabiting organisms; (c) organic gums contributing to formation and stability of soil aggregates for soil porosity; (d) complex organic molecules increasing the cation exchange capacity; (e) recycling of plant nutrients. Avoiding Stage-1 loss of this carbon on and in the soil upholds its integrity and usefulness, minimizes risks of Stage-2 losses by soil erosion, and thus improves and sustains the soil's productivity. Maize direct-drilled through wheat straw from the previous crop at Chapecó, Brazil. (T.F. Shaxson).

\subsection{Implications for policy}

Within governments, relatively independent departmental policies which at present are variously aimed at 'soil conservation', 'the environment', 'agriculture', etc., need an overarching agro-ecological policy framework that interconnects the concerns they have in common. These include soil conditions, biomass production, erosion, flooding, sedimentation, irrigation, and related matters, which are all linked through their common features of sustainability of organic potentials, soil porosity and water-use efficiency. The basis for such a framework should be a concern to encourage, develop and support systems of land use and soil management that are actively 'pro-biotic' with respect to life in the soil, at the same time discouraging those approaches of the past, which have allowed soils to degrade by default and inappropriate management, and which, in this sense, have turned out to be somewhat 'antibiotic'.

\subsection{A valid perspective}

The perspective outlined in this paper appears valid for two main reasons:

a. It suggests some credible alternatives to some commonlyheld but doubtful assumptions;

b. It offers a positive approach to enhancement of resources' value, agricultural sustainability, environmental improvement, and carbon sequestration, in contrast to the negative attitudes surrounding the difficulties of controlling soil erosion and the loss of carbon in runoff.
Prolonging the usefulness of carbon in living organisms and non-living residues in the soil also favors the formation, improvement and self-sustaining of its productivity as the rooting environment, as well as prolonging the usefulness of water within the soil and as streamflow. It thus contributes to the ongoing cyclical capability of plants and the associated soil biota to sequester carbon from the air.

Carbon captured from the atmosphere, in plants and other soil-inhabiting biota, is a key feature of effective strategies not only to minimize further erosional damage of productive soils, but also to recover, recuperate, and improve and maintain the resilience and productivity of those already damaged (Fig. 4).

\section{REFERENCES}

Allan R., Greenwood T. (1999) Advanced Biology 2. Work Sheet on transpiration, 1999, 1st ed., Learning Media Ltd., Glasgow, p. 80, ISBN 0-909031-29-0.

Bennett H.H. (1939) Soil conservation, McGraw-Hill Book Co., Inc., New York.

Bridges E.M., Hannam I.D., Oldeman L.R., Penning de Vries F.W.T., Scherr S.J., Sombatpanit S. (2001) Responses to land degradation, Science Publishers, Inc., Enfield, USA, ISBN 1-57808-152-1 (pbk.).

Chinene V.R.N., Shaxson T.F., Molumele P., Segerros M., Douglas M.G. (1996) Guidelines to Better Land Husbandry in the SADC Region. Agricultural Development Division, Commonwealth Secretariat, London (UK) + Environment and Land Management Sector of Southern African Development Community, Maseru, Lesotho.

Critchley W.R.S., Reij C.P., Turner S.D. (1992) Soil and water conservation in Sub-Saharan Africa, International Fund for Agricultural Development, Rome.

Derpsch R. (2001) Frontiers in conservation tillage and advances in conservation practice, in: Stott D.E., Mokhtar R.H., Steinhardt G.C. (Eds.), Sustaining the Global Farm - Selected papers from the 10th International Soil Conservation Organization Meeting, May 24-29, 1999, West Lafayette, IN., International Soil Conservation Organization in cooperation with the USDA and Purdue University, West Lafayette, IN., USA. CD-ROM available from the USDA-ARS National Soil Erosion Laboratory, West Lafayette, IN., USA.

Doolette J.B., Magrath W.B. (1990) Watershed development in Asia strategies and technologies, World Bank Technical Paper No. 127, The World Bank, Washington, USA, ISBN 0-8213-1606-0.

Downes R.G. (1978) The use and management of resources: a philosophy and concept for decision-making, in: Proc. Symp. 'Development of the SW region', Inst. of Engineers, Perth, Western Australia.

Downes R.G. (1982) Institution Building for Soil and Water Conservation in Brazil. Consultant's report to Project BRA/82/011, (in English and Portuguese): FAO (AGLS Division), Rome.

Downes R.G., Shaxson T.F., Douglas M.G. (1997) An ecological background to concepts of land husbandry, and principles of good land husbandry, Dorset, UK: Association for Better Land Husbandry, Occasional Paper.

Eswaran H., Lal R., Reich P.F. (2001) Land degradation: an overview, in: Bridges et al. (Eds.) q.v.

FAO. (2001) The life in soil, Agriculture 21 - Spotlight: Occasional Paper, FAO of United Nations (AGL Division), Rome.

Haigh M.J., Gentcheva-Kostadinova Sv. (2002) Erosion control on coalspoil banks: an evaluation, Ecol. Eng. 18, 371-377.

Hannam I.D. (2001) Ecological soil standards, in: Bridges et al. (Eds.) q.v. 
Hellin J., Haigh M.J. (2002) Impact of Vetiveria zizanioides (Vetiver grass) live barriers on maize production in Honduras, in: Sustainable Utilization of Global Soil and Water Resources, Proc. 12th International Soil Conservation Organization Conference, Beijing, 26-31 May 2002, Vol. 3, pp. 277-281 (in press).

Hudson N. (1981) Soil Conservation, Batsford, London, ISBN 0-71343521-6.

Hudson N. (1992) Land Husbandry, Batsford, London, ISBN 0-7314 5976 X.

Landers J.N. (1998) Zero tillage development in tropical Brazil, in: Proc. Workshop 'Conservation Tillage for Sustainable Agriculture', Harare, June 1998, Annexes. G.T.Z., Eschborn, pp. 247-262.

Landers J.N. (2001) Zero tillage in tropical Brazil - the story of a successful NGO activity, FAO Agricultural Services Bulletin 147, Food and Agriculture Organization of United Nations, Rome, ISBN 92-5-104672-7.

Lovelock J. (1988) The Ages of Gaia, Oxford University Press, Oxford, UK, ISBN 0-19-286090-9.

McGarry D. (2002) Soil compaction - the unnecessary form of land degradation!, Development and Cooperation, No. 3, May-June.

Morgan R.P.C. (1995) Soil Erosion and Conservation, Longman Group Ltd., London.

Mrabet R. (2002) Wheat yield and water-use efficiency under contrasting residue and tillage management systems in a semiarid area of Morocco, Exp. Agr. 38, 237-248.

Mrabet R., Ibno-Namr K., Bessam F., Saber N. (2001a) Soil chemical quality changes and implications for fertilizer management after 11 years of no-tillage wheat production systems in semi-arid Morocco, Land Degrad. Dev. 12, 505-517.

Mrabet R., Saber N., El-Brahli A., Bessam F. (2001b) Total, particulate organic matter and structural stability of a Calcixeroll under different wheat rotations and tillage systems in a semi-arid area of Morocco, Soil Till. Res. 57, 225-235.

Napier T.L. (2001) Soil and water conservation behaviours within the Mississippi River Basin, J. Soil Water Cons. (USA) 56, 279-285.

Pereira H.C. (1989) Policy and Practice in the Management of Tropical Watersheds, Westview Press, Boulder, USA, ISBN 1-85293-089-6.

Pieri C., Evers G., Landers J., O’Connell P., Terry E. (2002) No-Till Farming for Sustainable Rural Development, Agriculture and Rural Development Working Paper, IBRD/World Bank, Washington, DC.

Reicosky D.C. (2001) Conservation Agriculture: global environmental benefits of soil carbon management, Keynote paper at 1st World Congress on Conservation Agriculture, Madrid, 1-5 Oct. 2001, in: Garcia-Torres L., Benites J., Martinez-Vilela A. (Eds.), Conservation Agriculture, a worldwide challenge, FAO of United Nations, Rome + European Conservation Agriculture Federation, Brussels, Vol. 1, pp. 3-12, ISBN 84-932237-0-0.

Roose E. (1996) Introduction à la Gestion Conservatiore de l'Eau, de la Biomasse et de la Fertilité des Sols, Bulletin Pédologique de la FAO $n^{\circ} 70$, (Fr., Eng.), FAO of United Nations, Rome, ISBN 92$5-203451-\mathrm{X}$.

Shaxson T.F. (1981) Developing concepts of land husbandry for the tropics, in: Morgan R.P.C. (Ed.), Soil Conservation: Problems and
Prospects: Proc. International Conference 'Conservation 80', Wiley, Chichester, UK, pp. 351-362.

Shaxson T.F. (1993) Conservation-effectiveness of farmers' actions: a criterion of good land husbandry, in: Baum E., Wolff P., Zoebisch M. (Eds.), Topics in Applied Resource Management in the Tropics, Vol. 3, Acceptance of Soil and Water Conservation - Strategies and Technologies, D.I.T.S.L., Witzenhausen (Ger.), pp. 103128, ISBN 3-9801686-4-6.

Shaxson T.F. (1997) Soil erosion and land husbandry, Land Husbandry Inter. J. Soil Water Conserv. 2, 1-14.

Shaxson T.F. (1999) New concepts and approaches to land management in the tropics with emphasis on steeplands, FAO Soils Bulletin No. 75, Food and Agriculture Organization of United Nations, Rome, ISBN 92-5-104319-1.

Shaxson T.F., Barber R.G. (2003) Optimizing soil moisture for plant production - the significance of soil porosity, FAO Soils Bulletin No. 79, Food and Agriculture Organization of United Nations, Rome, ISBN 92-5-104944-0.

Shaxson F., Douglas M. (2004) Land Husbandry, in: Lal R. (Ed.), Encyclopedia of Soil Science, Marcel Dekker, New York.

Shaxson T.F., Hunter N.D., Jackson T.R., Alder J.R. (1977) A Land Husbandry Manual, Land Resources Conservation Department, Lilongwe, Malawi.

Shaxson T.F., Hudson N.W., Sanders D.W., Roose E., Moldenhauer W.C. (1989) Land Husbandry: A Framework for soil and water conservation, Soil and Water Conservation Society, Ankeny, USA, ISBN 0-935734-20-1.

Sonneveld B.G.J.S. (2002) Land under pressure - the impact of water erosion on food production in Ethiopia, Shaker Publishing, Maastricht, ISBN 90-423-0192-9.

Squire G.R. (1990) The physiology of tropical crop production, C.A.B. International, Wallingford, UK, ISBN 0-85198-677-3.

Stallings J.H. (1957) Soil: use and improvement, Prentice-Hall, Englewood Cliffs, USA, Library of Congress Catalog Card 57-5050.

Stocking M.A. (2003) Tropical soils and food security: the next 50 years, Science 302, 1356-1359.

Stocking M., Tengberg A. (1999) Integrated soil management for sustainable agriculture and food security in Southern and East Africa, FAO Paper AGL/Misc./23/99, Food and Agriculture Organization of United Nations, Rome, pp. 91-120.

Stocking M., Obando F., Tengberg A. (2002) Soil degradation and its impact on plants in drylands, in: Faz A., Ortiz R., Mermut A.H. (Eds.), Sustainable use and management of soils in arid and semiarid regions, Vol. 1, Quaderna Editorial, Murcia, Spain, ISBN 8495383-24-1, pp. 187-192.

Tea Research Stations (1963) Planting experiments, Annual Report 1962/63, Tea Assoc. of C. Africa, Mulanje, Malawi.

Tengberg A., Stocking M. (2001) Land degradation, food security, and agro-biodiversity - examining an old problem in a new way, in: Bridges et al. (Eds.), q.v.

Wild A. (1988) (Ed.), Russell's Soil Conditions and Plant Growth, 11th ed., Longman Scientific and Technical, Harlow, UK, ISBN 0-58244677-5.

Wrigley G. (1961) Tropical agriculture, Batsford, London. 